\title{
Selenium concentration of maize grain in South Africa and possible factors influencing the concentration
}

\author{
C. Courtman, J.B.J. van Ryssen ${ }^{\#} \&$ A. Oelofse \\ Centre for Nutrition, Department of Animal \& Wildlife Sciences, University of Pretoria 0002, Pretoria, South Africa
}

Copyright resides with the authors in terms of the Creative Commons Attribution 2.5 South African Licence.

See: http://creativecommons.org/licenses/by/2.5/za/

Condition of use: The user may copy, distribute, transmit and adapt the work, but must recognise the authors and the South African Journa of Animal Science

\begin{abstract}
A total of 896 maize grain samples were obtained from all the maize silos throughout South Africa (231 silos) and analysed for selenium (Se) content. This information was used to compile a regional distribution map of the Se content of maize grain in South Africa. Of the samples analysed, $94 \%$ contained below $50 \mu \mathrm{g}$ selenium $/ \mathrm{kg}$ DM and can thus be classified as deficient from an animal and human nutritional point of view. Maize grain in South Africa is therefore a poor source of Se for animals and humans. The geographical distribution of $\mathrm{Se}$ values of maize grain is consistent with that of previous studies on the $\mathrm{Se}$ status of herbivores in South Africa, suggesting that plants growing in most of the maize-producing areas of the country contain low concentrations of Se. However, these findings contradict those of the soil Se status in the country as reported by the Agricultural Research Council's Institute for Soil, Water and Climate, which states that the eastern part of the maize-producing areas of the country tends to have adequate to high soil Se levels and the western areas to have low levels. These contradictory results can be explained to a large extent by the varying soil $\mathrm{pH}$ throughout the country. Soil $\mathrm{pH}$ plays a primary role in the availability of selenium to plants. Although the eastern parts of the country tend to have high Se concentration in the soil, it is not available to the maize plant owing to a low soil $\mathrm{pH}$, while in the western parts of the country, where soil $\mathrm{pH}$ may be suitable for Se uptake by plants, there seems to be an inadequate concentration of available $\mathrm{Se}$ in the soil.
\end{abstract}

Keywords: Geographical map, soil pH, white maize, yellow maize

\#Corresponding author: jvryssen@up.ac.za

\section{Introduction}

Selenium (Se) is an essential micronutrient for the health and growth of humans and animals. Its functions in the body include its roles as an antioxidant through the Se-containing enzyme, glutathione peroxidase (GSH-Px), and as an activator of the thyroid hormones through Se-containing enzymes. Adequate Se thus strengthens the immune system and protects the body against conditions that compromise it, such as human immunodeficiency virus (HIV) (Surai, 2006; Fisinin et al., 2008). Dietary Se requirements of humans and animals are between 50 and $300 \mu \mathrm{g} \mathrm{Se} / \mathrm{kg}$ DM (Gissel-Nielsen et al., 1984; Elliot, 2006). It has been postulated that the vast majority of the world's human population has sub-optimal Se intakes (Haug et al., 2007; Fisinin et al., 2008). For a proportion of South African children, Se intakes have been estimated to be below two thirds of recommended dietary allowance (RDA) (Labadarios et al., 2005), which is 10 - $15 \mu \mathrm{g} \mathrm{Se}$ for infants, 20 - $30 \mu \mathrm{g}$ for children, $\pm 70 \mu \mathrm{g}$ for men and $\pm 55 \mu \mathrm{g}$ for women (NRC, 2000). In South Africa, maize grain is a staple food for humans and a major ingredient in the diets of intensively fed livestock. Therefore, Se in maize could potentially make a substantial contribution to the Se intake of both humans and livestock.

Selenium is not an essential element in plant nutrition, but may be incorporated into plant cells, replacing sulphur because sulphur and Se have similar chemical properties and compete for transporters at plant-root level (Lyons et al., 2004). The Se content of plants is determined by three main factors: the level of Se in the soil, the $\mathrm{pH}$ and redox equilibrium of the soil, and plant genetics (Reid \& Horvath, 1980; Haug 
et al., 2007). The presence of Se in the soil is affected by the Se content of the parent rock, the intensity of weathering and leaching, contamination of the soil (factories and the mining of other minerals) and atmospheric deposition of Se (Gissel-Nielsen et al., 1984). Selenium is more available to plants growing in high $\mathrm{pH}$ soils compared with low $\mathrm{pH}$ soils (Gissel-Nielsen et al., 1984). Therefore, fertilisers that are used to amend soils have an effect on the uptake of Se by plants (Gissel-Nielsen et al., 1984). Limestone fertilisation increases the soil $\mathrm{pH}$, while superphosphate decreases it. Selenium uptake by plants is also affected by the application of sulphur-containing fertilizers (Lyons et al., 2004).

The objective of this study was to determine the Se concentration of maize grain in South Africa. This would provide an indication of the contribution of maize grain to the Se intake of humans and animals in the country. In South Africa, humans preferably consume white maize, while yellow maize is used in animal diets (Esterhuizen \& Kreamer, 2011). Therefore, a comparison of the Se concentrations in yellow and white maize separately was considered noteworthy. Furthermore, the information was intended to map the geographical distribution of Se concentrations of maize in the country. Through that it was hoped to expand the map of the potential Se status of animals and their feed in South Africa, previously reported by Van Ryssen (2001).

\section{Materials and Methods}

A total of 896 maize grain samples were obtained from all the maize grain silos throughout South Africa (231 silos) and were analysed for Se at the UP-Nutrilab (Department of Animal and Wildlife Science, University of Pretoria). The samples were collected for the Grain Silo Industry (Pty) Ltd (Lynnwood Corporate Park, Lynnwood Manor, Pretoria) and supplied for the study by the Southern African Grain Laboratory (www.sagl.co.za). The samples were from the 2008 - 2009 planting season. Samples were analysed using the continuous hydride generation atomic absorption method (AOAC, 2000) and samples were read using a Perkin-Elmer 2380 Atomic Absorption Spectrophotometer at an absorbency of $196 \mathrm{~nm}$ and lamp energy of $16 \mathrm{~mA}$. Peach leaves were used as standard reference material (SRM) (SRM 1547, National Institute of Standards and Technology, US Department of Commerce, Gaithersburg, MD 20899) and included in each batch of analyses to verify the accuracy of the Se assays. To obtain an indication of the geographical distribution of the Se content of maize grain in South Africa, samples were classified in rather arbitrary groups of less than $12 \mu \mathrm{g}, 12-25 \mu \mathrm{g}, 26-40 \mu \mathrm{g}$ and above $40 \mu \mathrm{g} \mathrm{Se} / \mathrm{kg}$ DM. However, maize samples were not obtained from all the maize-producing regions of the country because in some areas there are apparently no grain silos, for example in Griqualand East, Transkei, Ciskei and KwaZulu-Natal Midlands, except for a silo at Dalton near Greytown.

\section{Results and Discussion}

Considering that the Se requirements of human and animals are between 50 and $300 \mu \mathrm{g} \mathrm{Se} / \mathrm{kg} \mathrm{DM}$, depending on physiological stage (Gissel-Nielsen et al., 1984; Elliot, 2006), it is of importance to note that $94 \%$ of the analysed samples contained below $50 \mu \mathrm{g} \mathrm{Se} / \mathrm{kg}$, and thus can be classified as deficient. Results from the survey showed that $46 \%$ of the maize samples contained $<12 \mu \mathrm{g} \mathrm{Se} / \mathrm{kg}$ DM; $30 \%$ were between 12 and $25 \mu \mathrm{g} \mathrm{Se} / \mathrm{kg} \mathrm{DM} ; 12 \%$ were between 26 and $40 \mu \mathrm{g} \mathrm{Se} / \mathrm{kg} \mathrm{DM}$; and only $10 \%$ of the samples contained $>40 \mu \mathrm{g} \mathrm{Se} / \mathrm{kg}$ DM (Table 1).

Yellow maize generally had lower Se values than the white maize. However, yellow and white maize varieties were not distributed evenly in the various regions. For example, only yellow maize varieties have been obtained from silos at Vaalhartz and along the Orange and Vaal rivers. Therefore, it was considered not valid to perform a statistical comparison between the white and yellow maize samples.

Figure 1 depicts the geographical distribution of Se in maize according to the classes decided upon. Most areas, as mentioned above, are deficient in Se. That is, large portions of central and eastern Gauteng, central and western North West and a narrow strip of the central to western Free State have maize with low Se levels. A large proportion (26\%) of the samples contained no Se and originated mainly from large areas of Mpumalanga, the southern region of Limpopo, northern KwaZulu-Natal, central and eastern Free State, as well as an area extending from the Vaalhartz irrigation scheme and along the Orange and Vaal rivers. Maize samples classified as marginally deficient to adequate $(>40 \mu \mathrm{g} / \mathrm{kg} \mathrm{DM})$ were collected from the northwestern Free State and North West near Christiana and the remaining silos in Limpopo. However, it should be noted that this distribution does not depict the total amount of maize produced in the different regions. The map of the regional distribution of the Se concentration of maize grain in South Africa, compiled from 
this survey, agrees to a large extent with Van Ryssen's (2001) map for these grain-producing areas, albeit the 2001 map does not include much data from the North West Province and central Free State.

Table 1 Selenium concentrations of yellow and white maize grain samples collected from maize grain silos throughout South Africa

\begin{tabular}{|c|c|c|c|c|c|c|}
\hline \multirow[b]{2}{*}{$\begin{array}{c}\text { Selenium } \\
\text { concentration } \\
(\mu \mathrm{g} / \mathrm{kg} \mathrm{DM})\end{array}$} & \multicolumn{2}{|c|}{ Yellow maize samples } & \multicolumn{2}{|c|}{ White maize samples } & \multicolumn{2}{|c|}{ Total } \\
\hline & $\begin{array}{c}\text { No. of } \\
\text { samples } \\
\text { (\% of total) }\end{array}$ & $\begin{array}{c}\text { Median } \\
(\mu \mathrm{g} / \mathrm{kg} \mathrm{DM})\end{array}$ & $\begin{array}{c}\text { No. of } \\
\text { samples } \\
\text { (\% of total) }\end{array}$ & $\begin{array}{c}\text { Median } \\
(\mu \mathrm{g} / \mathrm{kg} \mathrm{DM})\end{array}$ & $\begin{array}{c}\text { No. of } \\
\text { samples } \\
\text { (\% of total) }\end{array}$ & $\begin{array}{c}\text { Median } \\
(\mu \mathrm{g} / \mathrm{kg} \mathrm{DM})\end{array}$ \\
\hline$<12$ & $240(58 \%)$ & 0 & $176(37 \%)$ & 0 & $416(46 \%)$ & 0 \\
\hline $12-25$ & $125(30 \%)$ & 15 & $140(29 \%)$ & 15 & $265(30 \%)$ & 15 \\
\hline $26-40$ & $31(7 \%)$ & 30 & $76(16 \%)$ & 30 & $107(12 \%)$ & 30 \\
\hline$>40$ & $16(4 \%)$ & 55 & $71(15 \%)$ & 59 & $87(10 \%)$ & 59 \\
\hline
\end{tabular}

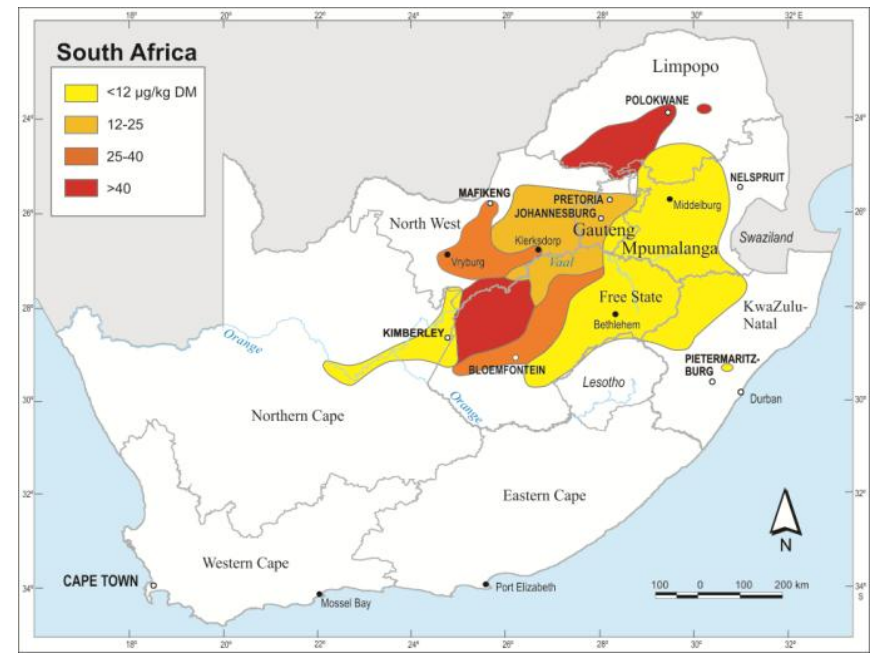

Figure 1 The regional distribution of the selenium concentration $(\mu \mathrm{g} / \mathrm{kg} \mathrm{DM})$ of maize grain in South Africa obtained from the maize grain silos in the country.

However, when comparing this map of the Se concentration in maize grain (Figure 1) with the map of the soil Se status in South Africa (Figure 2), discrepancies are noted. The soils in large parts of Mpumalanga, northern KwaZulu-Natal and northern Free State, and areas of North West and central to eastern Free State contain high concentrations of Se, while the maize grain originating from these regions contained very little, if any, Se. In an investigation on the Se status of free-ranging livestock and game in the eastern regions of the Free State and Mpumalanga, Van Ryssen (2006) concluded that the Se status of these animals indicated a general Se deficiency, thus supporting the results from the survey on the Se content of maize from these regions.

Even though Oldfield (1999) stated that the Se concentration in soils is generally reflected by the Se content of plants growing in those soils, it is suggested that the reason for the discrepancy between the soil Se and maize Se maps in the present study could be the influence of soil $\mathrm{pH}$ on the Se uptake of the maize plant. It is well documented that $\mathrm{Se}$ in the soil is readily available to plants if the soil $\mathrm{pH}$ is in the alkaline range (Reid \& Horvath, 1980). According to Figure 3, the general trend is that soils in the eastern parts of the maize-producing regions of South Africa have a low $\mathrm{pH}$ (acidic), while the soils in the western regions tend to have a moderate to high $\mathrm{pH}$. This suggests that although the soils in the eastern parts of the country tend to have a high Se content, the Se is not available to the maize plants owing to the low soil $\mathrm{pH}$. Van Ryssen (2006) suggested that the problem of Se availability to plants is probably exacerbated by the problem of acid 
rain and sulphur contamination in large areas of Mpumalanga and north-eastern Free State. It should be noted that the contribution of soil fertilization practices to the availability of Se in the soil have not been established in this study.

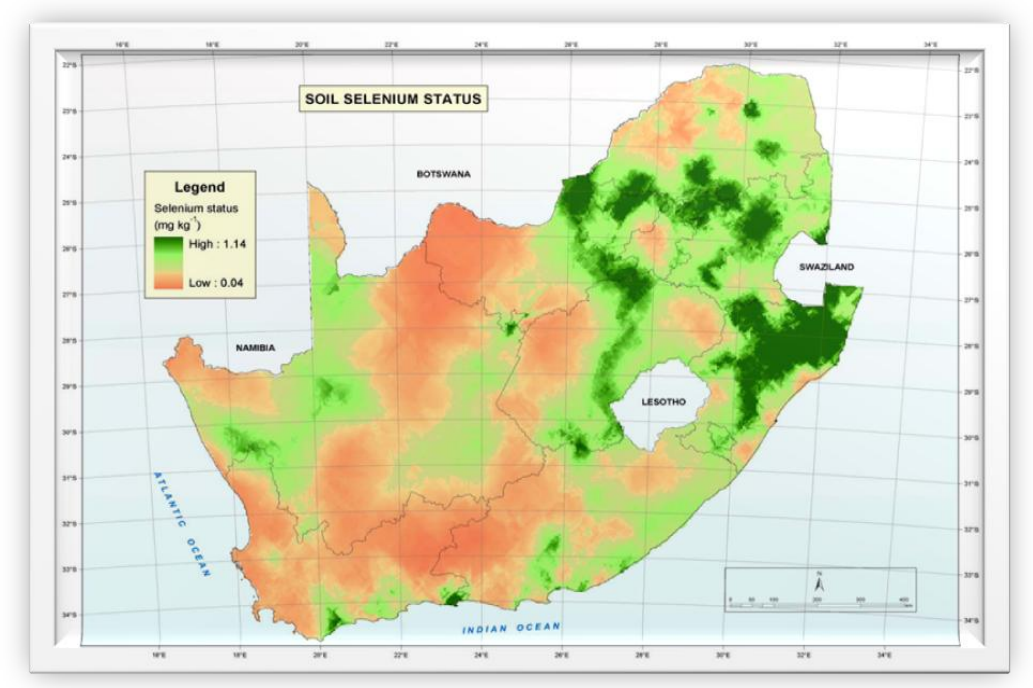

Figure 2 Map of soil selenium status $(\mathrm{mg} / \mathrm{kg}$ ) in South Africa (with permission of the Institute for Soil, Water and Climate, Agricultural Research Council, South Africa).

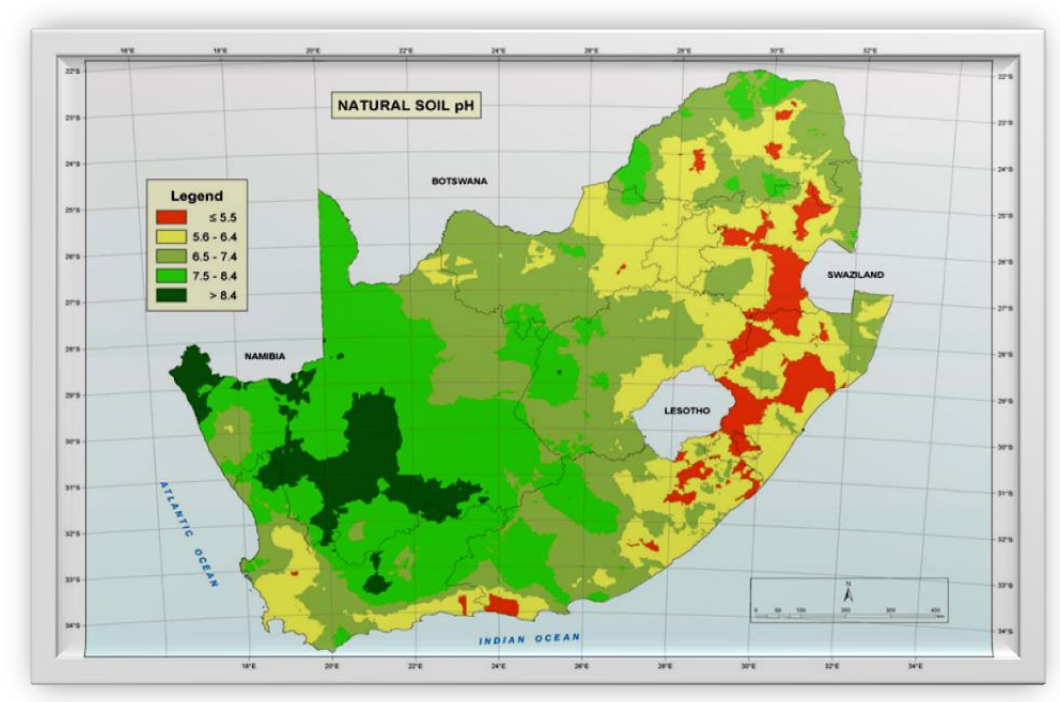

Figure 3 Map of the soil $\mathrm{pH}$ of South African soils (with permission of the Institute for Soil, Water and Climate of the Agricultural Research Council, South Africa).

According to Figure 3, in the western regions of the maize-producing areas of the country, the soil $\mathrm{pH}$ might be suitable for the uptake of Se by plants, but the Se content in the soil seems inadequately low. In the irrigation areas of Vaalhartz and along the Orange and Vaal rivers leaching of Se from the soils might have contributed to a low Se in those soils, as noted by Van Ryssen (2001). The consequence is that the maize grain samples from these regions also contained very little, if any, Se.

\section{Conclusion}

Maize grain in South Africa is a poor source of Se for both human and animal nutrition, with 94\% of the samples containing less than requirements. Since maize grain is a major component in the diet of a large portion of the human population in South Africa, the low Se concentration in most of the maize grain in the 
country could contribute to the inadequate intake of Se by many South African children, as pointed out by Labadarios et al. (2005). This could compromise their immunity and resistance to health problems such as HIV and tuberculosis.

In the South African livestock industry, animal feed consultants, feed suppliers and veterinarians are quite aware of the problem of a Se deficiency, and Se supplementation to livestock is a fairly common practice in the country. This is supported by laboratory services, such as UP-Nutrilab, where the Se status of animals and the Se content of feed are measured. This is useful, since Se is one of the few elements in mineral nutrition where liver and blood concentrations are fairly well correlated with Se intake, and thus the Se nutritional status of the animal, even into the adequacy and the toxic ranges of intakes (Van Ryssen, 2003; Van Ryssen et al., 2011).

\section{Acknowledgements}

The authors wish to acknowledge the National Research Foundation (SUR 2008062300006) for funding the project, the Grain Silo Industry (Pty) Ltd for granting permission to analyse the maize sample, and Truida Smit from the University of Pretoria's Nutrilab for the analyses of the maize grain samples.

\section{References}

AOAC, 2000. Official Methods of Analysis: Association of Official Analytical Chemists, Inc., Arlington, Virginia, USA. Official method 996.16. Chapter 4, pp. 45-49.

Elliot, S.A., 2006. Dynamics of selenium nutrition of animals in relation to human health. Intermountain Nutrition Conference Proceedings. Salt Lake City.

Esterhuizen, D. \& Kreamer, R., 2011. Grain and feed update: Republic of South Africa. Global Agricultural Information Network, quarterly update. (www.grainsa.co.za).

Fisinin, V.I., Papazyan, T.T. \& Surai, P.F., 2008. Producing specialist poultry products to meet human nutrition requirements: selenium enriched eggs. Wrld's Poult. Sci. J. 64, 85-98.

Gissel-Nielsen, G., Gupta, U.C., Lamand, M. \& Westermarck, T., 1984. Selenium in soils and plants and its importance in livestock and human nutrition. Adv. Agron. 37, 397-460.

Haug, A., Graham, R.D., Christophersen, O.A. \& Lyons, G.H., 2007. How to use the world's scare selenium resources efficiently to increase the selenium concentration in food. Microb. Ecol. Health Disease 19, 209-228.

Labadarios, D., Steyn, N.P., Maunder, E., MacIntyre, U., Gericke, G., Swart, R., Huskisson, J., Dannhauser, A., Vorster, H.H., Nesamvuni, A.E. \& Nel, J.H., 2005. The national food consumption survey: South Africa, 1999. Public Health Nutr. 8 (5), 533-543.

Lyons, G.H., Lewis, J., Lorimer, M.F., Holloway, R.E., Brace, D.M. \& Stangoulis, J.C.R., 2004. High selenium wheat: agronomic biofortification strategies to improve human nutrition. Food Agric. Environ. 2, 171-178.

NRC, 2000. Dietary reference intakes for vitamin C, vitamin E, selenium and carotenoids. National Research Council, The National Academy Press. Washington, D.C., USA.

Oldfield, J.E., 1999. Selenium World Atlas. Publisher: Selenium-Tellurium Development Association, Grimberger, Belgium.

Reid, R.L. \& Horvath, D.J., 1980. Soil chemistry and mineral problems in farm livestock: a review. Anim. Feed Sci. Technol. 5, 95-167.

Surai, P.F., 2006. Selenium in Nutrition and Health. Nottingham University Press, Nottingham, UK.

Van Ryssen, J.B.J., 2001. Geographical distribution of the selenium status of herbivores in South Africa. S. Afr. J. Anim. Sci. 31, 1-8.

Van Ryssen, J.B.J., 2003. Predicting the mineral status of livestock from laboratory analyses. Ch 8. Proc. Information Day on Laboratory analyses on feeds and animal tissues. University of Pretoria. 26 Febr 2003. pp. 84-101.

Van Ryssen, J.B.J., 2006. An evaluation of the trace element nutritional status of grazers in the eastern regions of the Free State and Mpumalanga. SA-ANIM SCI, vol. 7, pp. 22-30. http://www.sasas.co.za/sites/sasas.co.za/files/VanRyssenPop06.pdf

Van Ryssen, J.B.J., Coertze, R.J. \& Smith, M.F., 2011. Association between measurements of assessing selenium status of sheep. $62^{\text {nd }}$ Annual Meeting of the European Federation of Animal Science. 29 August to 2 September 2011, Stavanger, Norway. 